\title{
PENGEMBANGAN BANK SOAL DAN PEMBAHASAN UJIAN NASIONAL BERBASIS MULTIMEDIA PEMBELAJARAN INTERAKTIF DENGAN MACROMEDIA AUTHORWARE 7.0
}

\author{
Sunarti ${ }^{1}$ dan Deri Anggraini \\ PGSD Universitas PGRI Yogyakarta (email: 1bunartisadja@gmail.com)
}

\begin{abstract}
Abstrak: Pengembangan Bank Soal dan Pembahasan Ujian Nasional Berbasis Multimedia Pembelajaran Interaktif dengan Macromedia Authorware 7.0. Penelitian ini bertujuan untuk mengembangkan bank soal dan pembahasan UN SD berbasis multimedia pembelajaran interaktif dengan macromedia authorware 7.0. Penelitian menggunakan desain penelitian pengembangan yang diadaptasi dari model penelitian pengembangan. Penelitian ini telah berhasil mengembangkasan bank soal dan pembahasan UN SD berbasis multimedia pembelajaran yang dikemas dalam bentuk CD pembelajaran dan telah divalidasi oleh ahli materi dan ahli media, serta telah diujicobakan pada pengguna produk. Ditinjau dari aspek isi dan pembelajaran validator menilai kualitas produk sangat baik. Dengan menggunakan rentang skor 1 sampai 5, skor rata-rata aspek isi 4,67, aspek pembelajaran 4,68, aspek tampilan 3,95, dan pemrograman 4,13. Aspek daya tarik menunjukkan bahwa produk sangat menarik dengan skor rata-rata 4,15. Hasil uji coba menunjukkan bahwa persentase ketuntasan belajar latihan UN IPA rata-rata $85 \%$ (baik), Bahasa Indonesia mencapai rata-rata 90\% (sangat baik), dan Matematika 31\% (sangat kurang). Produk ini diharapkan mampu untuk membantu siswa dalam mempersiapkan UN SD.
\end{abstract}

Kata Kunci: pengembangan bank soal, multimedia, pembelajaran interaktif, UN

Abstract: Development of The Interactive Learning Multimedia-Based National Examination Item Bank and Its Discussion Using The Macromedia Authorware 7.0. This study aimed to develop the interactive learning multimedia-based Elementary School National Examination (UN SD) item bank and its discussion using Macromedia Authorware 7.0. The development research model of Borg \& Gall, Arief S, Sadiman et al., and Sugiyono was used in this study. This research was successfully to develop the interactive learning multimedia-based UN SD item bank and its discussion in learning CD and validation was carried out by material and media experts, and trials were also conducted among product users. From the content and learning aspects, the product was assessed as excellent by the validators. Based on the scale of 1 to 5 , the average scores of content, learning, display, and programming aspects were 4.67, 4.68, 3.95, and 4.13, respectively. From interest aspect, it was shown that the product was highly interesting averaged of 4.15. From the trial, the percentage of students' learning mastery in Science, Bahasa Indonesia, Mathematics UN trials were $85 \%, 90 \%$, and $31 \%$ in 
averages with the criteria of good, excellent, very poor, respectively.It is expected that this product will be able to assist Elementary School students in preparing their UN.

Keywords: development, multimedia, National Examination

\section{PENDAHULUAN}

Teknologi Informasi dan Komunikasi (TIK) di Indonesia berkembang pesat. Secara fundamental, hal tersebut membawa perubahan dalam inovasi penyelenggaraan pendidikan. Salah satu wujud pendayagunaan TIK dalam pendidikan adalah maraknya pengembangan multimedia pembelajaran interaktif sebagai salah satu media pembelajaran inovatif sehingga pemanfaatan komputer untuk program pembelajaran inovatif terus mengalami peningkatan. Pemakaian bahan ajar berbasis komputer dalam proses pembelajaran sudah banyak dijumpai di sekolah-sekolah. Guru memanfaatkan CD interaktif untuk membelajarkan siswa. Bahan ajar tersebut memiliki beragam bentuk variasi, ada yang berbentuk permainan, soal-soal, dan ada pula yang berbentuk materi bahan ajar.

Pendayagunaan teknologi informasi dan komunikasi membawa dampak positif dalam dunia pendidikan. Siswa dapat belajar dan mendapatkan informasi yang dibutuhkan dari mana saja, kapan saja, dan dari siapa saja. Melihat dampak positif pendayagunaan TIK, perlu adanya upaya untuk mengembangkan fasilitas belajar bagi siswa kelas VI yang akan menghadapi Ujian Nasional (UN). UN adalah ujian nasional yang dilaksanakan secara terintegrasi dalam pe- laksanaan ujian sekolah/madrasah untuk Sekolah Dasar/Madrasah Ibtidaiyah/Sekolah Dasar Luar Biasa (SDMI/ SDLB).

Badan Standar Nasional Pendidikan (BSNP) merumuskan pengertian bahwa Ujian Nasional (UN) adalah penilaian hasil belajar oleh pemerintah yang bertujuan untuk menilai pencapaian kompetensi lulusan secara nasional pada mata pelajaran tertentu dalam kelompok ilmu pengetahuan dan teknologi (Permendiknas No. 20, 2007). UN bertujuan untuk menilai pencapaian kompetensi lulusan secara nasional pada mata pelajaran Bahasa Indonesia, Matematika, dan Ilmu Pengetahuan Alam (IPA) dalam rangka pencapaian target wajib belajar pendidikan dasar yang bermutu. Fungsi UN sebagai salah satu pertimbangan untuk pemetaan mutu satuan pendidikan, dasar seleksi masuk jenjang pendidikan selanjutnya, penentuan kelulusan peserta didik dari program dan/atau satuan pendidikan, dasar pembinaan dan pemberian bantuan kepada satuan pendidikan dalam upaya meningkatkan mutu pendidikan.

Berbagai upaya dalam rangka mempersiapkan para siswa untuk menghadapi UN dilakukan oleh pihak sekolah. Salah satunya adalah memberikan tambahan pelajaran melalui les di sekolah. Dalam kegiatan les di sekolah, guru 
biasanya mengajak siswa untuk mengerjakan soal UN tahun-tahun sebelumnya. Setelah mengerjakan, siswa mengikuti pembahasan yang disampaikan oleh guru. Proses tersebut menjadi rutinitas harian siswa menjelang UN.

Salah satu dampak yang ditimbulkan dari rutinitas tersebut adalah siswa mengalami kejenuhan belajar. Oleh karena itu, perlu dilakukan upaya peningkatan kualitas pembelajaran melalui penataan semua komponen, baik masukan instrumental (pendidik, kurikulum dan bahan ajar, iklim pembelajaran, media belajar, fasilitas belajar, dan materi belajar) maupun masukan potensial (kesiapan belajar, motivasi, latar belakang sosial budaya, bekal ajar awal, gaya belajar, serta kebutuhan dan harapannya), sedemikian rupa sehingga secara sinergis mampu menghasilkan proses, hasil, dan dampak belajar yang optimal. Salah satunya, melalui pendayagunaan TIK untuk mengembangkan bank soal dan pembahasan yang dapat digunakan untuk membantu siswa belajar secara mandiri.

Pengembangan Bank Soal dan Pembahasan Ujian Nasional Berbasis Multimedia Pembelajaran Interaktif dengan Macromedia Authorware 7.0 penting dilaksanakan untuk membantu siswa dalam mempersiapkan diri menghadapi UN. Mengingat banyaknya materi yang harus dikuasai oleh siswa, pembelajaran perlu dirancang sedemikian rupa sehingga materi yang banyak tersebut tetap dapat dikuasai oleh siswa. Keberadaan komputer yang telah meluas sampai tingkat sekolah dasar saat ini perlu digunakan untuk meningkatkan prestasi, khususnya dalam persiapan
UN. Melalui pembelajaran berbantuan computer, akan tercipta pembelajaran yang aktif, inovatif, kreatif, efektif, dan menyenangkan. Dengan demikian, peluang siswa mengalami kejenuhan belajar akan semakin kecil.

Multimedia adalah media yang menggabungkan dua unsur atau lebih media yang terdiri dari teks, grafis, gambar, foto, audio, video, dan animasi secara terintegrasi. Daryanto (2010:53) mengemukakan bahwa karakteristik multimedia pembelajaran adalah: (1) memiliki lebih dari satu media yang konvergen, misalnya menggabungkan unsur audio dan visual; (2) bersifat interaktif, dalam pengertian memiliki kemampuan untuk mengakomodasi respons pengguna; dan (3) bersifat mandiri, dalam pengertian memberi kemudahan dan kelengkapan isi sedemikian rupa sehingga pengguna bisa menggunakan tanpa bimbingan orang lain. Sanjaya (2009:219) mengemukakan bahwa kelebihan multimedia adalah dapat menggabungkan semua unsur media, seperti teks, video, animasi, gambar, grafik, dan suara menjadi satu-kesatuan penyajian sehingga mengakomodasi sesuai dengan modalitas belajar siswa. Kustandi dan Sutjipto (2011:78) menambahkan kelebihan multimedia yaitu memberikan kemudahan kepada siswa belajar secara individual maupun kelompok, memberikan kemudahan bagi guru dalam menyampaikan materi, dan meningkatkan motivasi belajar siswa.

Sanjaya (2009:222) memaparkan kelebihan CD interaktif, yaitu (1) membimbing siswa secara tuntas untuk menguasai materi dengan cepat dan menarik; (2) siswa dapat belajar secara 
mandiri, tidak harus tergantung kepada guru/instruktur; (3) siswa dapat memulai belajar kapan saja dan dapat mengakhiri sesuai keinginannya; (4) siswa dapat memraktikkan secara langsung materi-materi yang diajarkan; dan (5) siswa dapat mengulangi mempelajari materi untuk penguasaan materi secara menyeluruh. Selain bagi siswa, bahan ajar yang berbasis multimedia juga meningkatkan peran pendidik sebagai fasilitator (Widodo \& Jasmadi, 2008:36).

Authorware merupakan salah satu produk unggulan Macromedia, seperti halnya Macromedia Flash, Director, Dreamweaver, Fireworks, dan sebagainya. Macromedia Authorware 7.0 merupakan software yang tepat untuk membuat berbagai bentuk sajian visual yang dapat mengintepretasikan berbagai media, seperti video, animasi, gambar, dan suara sehingga program ini cukup handal dalam pembuatan berbagai macam aplikasi tutorial yang interaktif dan menarik. Penggunaan ikon dan flowline yang menjadi dasar pengoperasioan Authorware memberikan kemudahan dalam membuat aplikasi tutorial. Tampilan Authorware 7.0 secara umum terdiri atas enam bagian, yaitu Toolbar, Palet Icons, Toolbox, Tool Panel, Property Inspector, dan Flowline. Tim Penelitian dan Pengembangan Wahana Komputer (2004: 23-32) menjelaskan masing-masing bagian tersebut sebagai berikut. Pada toolbar terdapat beberapaikon, di antaranya New, Open, Save All, Import, Undo, Cut, Copy, Paste, Find, Tes Styles List, Bold, Italic, Underline, Restart, Control Panel, Function, Variables, dan Knowledge Objects. Palet icons mempunyai ikon-ikon dengan fungsi yang berbeda. Jenis-jenis ikon tersebut adalah Display, Motion, Ersae, Wait, Navigate, Framework, Decision, Interaction, Calculation, Map, Digital Movie, Sound, DVD, Knowledge Object, Start and Stop Flag, dan Color Palette. Toolbox merupakan bagian Authorware 7.0 yang berfungsi dalam pengolahan teks dan gambar. Toolbox hanya akan muncul dan dapat digunakan pada saat dilakukan pengeditan terhadap isi ikon pada Presentation Window. Tool Panel memiliki tiga jenis palet, yaitu Function, Variables, dan Knowledge Objects. Tool Panel digunakan untuk menampilkan ketiga palet tersebut. Palet Function berisi kumpulan fungsi yang dimiliki oleh Authorware. Palet Variables berisi kumpulan variabel yang dimiliki oleh $A u$ thorware. Palet Knowledge object berisi kumpulan Knowledge objects yang dimiliki oleh Authorware. Property Inspector digunakan untuk menampilkan nilai atau setting property sebuah ikon. Setting masing-masing ikon juga dapat diatur melalui panel Property Inspector.Flowline digunakan untuk menempatkan ikonikon dengan fungsinya masing-masing, sesuai dengan skenario tutorial. Caranya dengan mengklik ikon yang diinginkan dari Palet Icons dan menarik (drag) ikon tersebut hingga ke area kerja dekat flowline, maka icon akan menempel pada flowline tepat di tanda

Tujuan penelitian ini sebagai berikut. Pertama, mengembangkan bank soal dan pembahasan Ujian Nasional SD berbasis multimedia pembelajaran interaktif dengan Macromedia Authorware 7.0 untuk membantu meningkatkan kematangan persiapan siswa dalam menghadapi Ujian Nasional. Kedua, mengungkapkan kualitas bank soal dan 
pembahasan Ujian Nasional SD berbasis multimedia pembelajaran interaktif dengan Macromedia Authorware 7.0 ditinjau dari aspek isi, pembelajaran, tampilan, dan pemrograman. Ketiga, mengetahui aspek daya tarik bank soal dan pembahasan Ujian Nasional SD berbasis multimedia pembelajaran interaktif dengan Macromedia Authorware 7.0 yang telah dikembangkan. Keempat, mengetahui ketuntasan belajar siswa setelah belajar dengan menggunakan bank soal dan pembahasan Ujian Nasional SD berbasis multimedia pembelajaran interaktif dengan Macromedia Authorware 7.0.

Dalam pengembangan multimedia pembelajaran perlu diperhatikan tahaptahap tertentu yang harus dilalui. Hal ini dilakukan agar dapat menghasilkan suatu produk mutimedia pembelajaran yang baik dan layak untuk digunakan sebagai media pembelajaran. Sadiman dkk. (2006:100) mengatakan bahwa pengembangan media meliputi enam langkah, yaitu: (1) menganalisis kebutuhan dan karakteristik siswa; (2) merumuskan tujuan instruksional; (3) merumuskan materi secara terperinci; (4) mengembangkan alat pengukur keberhasilan; (5) menulis naskah media; dan (6) mengadakan tes dan revisi. Sementara itu, Adi (2003:5-6) menyatakan bahwa prosespengembangan multimedia pembelajaran mengikuti lima langkah, yaitu: (1) melakukan proses analisis, yaitu menemukan kebutuhan apa saja yang diperlukan untuk membuat multimedia; (2) membuat desain multimedia yaitu membuat storyboard atau alur cerita; (3) melakukan pengembangan, yaitu membuat motion effect, transisi, struktur navigasi, dan data variabel; (4) melaksanakan evaluasi yaitu menguji produk dengan melibatkan audience yang sesungguhnya; dan (5) melakukan pendistribusian, yaitu mengemas hasil karya untuk didistribusikan.

\section{METODE}

Penelitian ini dilaksanakan di tiga SD di Kabupaten Kulon Progo, yaitu SD Negeri Percobaan 4, SD Negeri Kalimenur, dan SD Negeri 1 Pengasih. Penelitian dilaksanakan pada 8 Februari 2011 sampai 31 Januari 2012. Model yang menjadi acuan adalah model penelitian pengembangan Borg \& Gall (2003), Sadiman dkk. (2006), dan Sugiyono (2009). Pengembangan bank soal dan pembahasan Ujian Nasional berbasis multimedia pembelajaran interaktif dengan Macromedia Authorware 7.0 ditempuh dengan serangkaian kegiatan, seperti: (1) analisis kebutuhan; (2) desain pembelajaran; (3) produksi multimedia; (4) validasi desain; (5) revisi desain; (6) uji coba produk; (7) revisi produk; dan (8) produk akhir.

Pengujian untuk mengembangkan bank soal dan pembahasan Ujian Nasional berbasis multimedia pembelajaran interaktif dengan Macromedia Authorware 7 dalam penelitian ini dilakukan lima kali dengan menggunakan desain Single one shot Case Study. Desain uji coba digambarkan pada Gambar 1.

Pengumpulan data dilakukan dengan menggunakan angket respons, wawancara, observasi, dan tes sehingga jenis data yang diperoleh dalam penelitian ini adalah data kualitatif dan kuantitatif. Data kualitatif berupa komentar dan saran perbaikan produk 


\begin{tabular}{|l|l|}
\hline Uji Coba 1 & Uji Coba Perseorangan \\
\hline Uji Coba 2 & $\mathrm{X}_{1} \mathrm{O}_{1}$ \\
\hline Uji Coba 3 & Uji Coba Lapangan I \\
\hline Uji Coba 4 & $\mathrm{X}_{2} \mathrm{O}_{2}$ \\
\hline Uji Coba 5 \\
\hline
\end{tabular}

Gambar 1: Desain Single One Shot Case Study.

X : Treatment berupa penerapan multimedia pembelajaran interaktif dengan Macromedia Authorware 7.0

0 : Observasihasil dari penerapan multimedia pembelajaran interaktif dengan Macromedia Authorware 7.0

dari ahli materi dan ahli media. Data kuantitatif yakni data berupa skor penilaian ahli materi dan ahli media, skor hasil observasi, skor hasil angket guru dan siswa, serta skor tes yang diperoleh siswa dalam setiap uji coba. Instrumen yang digunakan adalah angket, pedoman wawancara, pedoman observasi, dan tes.

Teknik analisis data yang digunakan adalah statistik deskriptif. Data kualitatif dianalisis dan dideskripsikan secara deskriptif kualitatif. Data kuantitatif dianalisis dan dideskripsikan secara deskriptif kuantitatif. Data kuantitatif skor penilaian ahli materi, ahli media, dan daya tarik produk dianalisis dengan acuan tabel konversi nilai yang diadaptasidariSudijono (2008:329). Data skor hasil belajar selama uji coba dianalisis dengan menghitung persentase siswa yang telah mencapai ketuntasan belajar $(\geq 60)$. Persentase ketuntasan belajar diubah menjadi data kualitatif berpedoman pada acuan konversi nilai menurut Bloom, Madaus \& Hastings (1981).

\section{HASIL DAN PEMBAHASAN}

Penelitian ini telah berhasil mengembangkan bank soal dan pembahasan UN SD berbasis multimedia pembelajaran interaktif dengan macromedia authorware 7.0 yang dikemas dalam format CD pembelajaran dan telah divalidasi oleh ahli materi dan ahli media, serta telah diujicobakan pada pengguna produk.

\section{Validasi Ahli Materi}

Data validasi ahli materi diperoleh melalui angket. Dari hasil analisis, diperoleh rata-rata skor penilaian ahli materi untuk aspek isi adalah 4,67. Dengan menggunakan rentang skor 1 sampai 5, rata-rata skor penilaian ahli materi untuk aspek isi tergolong kriteria sangat baik. Rata-rata skor penilai- 
an ahli materi untuk aspek pembelajaran adalah 4,68 , rata-rata skor penilaian ahli materi untuk aspek pembelajaran tergolong kriteria sangat baik. Secara rinci, hasil validasi ahli materi disajikan dalam Tabel 1.

\section{Validasi Ahli Media}

Data validasi ahli media diperoleh melalui angket. Dari hasil analisis, diperoleh rata-rata skor penilaian ahli media untuk aspek tampilan adalah 3,95 Dengan menggunakan rentang skor 1 sampai 5, rata-rata skor aspek tampilan tergolong tergolong kriteria baik. Rata-rata skor penilaian aspek pemrograman adalah 4,13. Rata-rata skor penilaian ahli media untuk aspek pemrograman tergolong kriteria baik. Secara rinci, hasil validasi ahli media disajikan dalam Tabel 2.

\section{Uji Coba Produk}

Dari aspek ketertarikan, hasil analisis data uji coba menunjukkan bahwa rata-rata skor ketertarikan siswa terhadap Bank Soal dan Pembahasan UN yang dikembangkan pada uji coba lapangan 4,15. Dengan menggunakan rentang skor 1 sampai 5, rata-rata skor ketertarikan siswa tergolong kriteria sangat menarik. Secara rinci, hasil uji coba disajikan pada Tabel 3.

Dari aspek ketuntasan belajar, hasil uji coba lapangan, rata-rata ketuntasan belajar IPA 85\%, tergolong kriteria baik, rata-rata ketuntasan belajar Bahasa Indonesia 90\%, tergolong kriteria sangat baik, rata-rata ketuntasan belajar Matematika 31\%, tergolong kriteria sangat kurang. Secara rinci, hasil uji coba disajikan pada Tabel 4.

Tabel 1: Hasil Validasi Ahli Materi

\begin{tabular}{lllll}
\hline Mata Pelajaran & Aspek Isi & Kategori & $\begin{array}{l}\text { Aspek } \\
\text { Pembelajaran }\end{array}$ & Kategori \\
\hline IPA & 4.85 & Sangat Baik & 4.9 & Sangat Baik \\
Bahasa Indonesia & 4.85 & Sangat Baik & 5 & Sangat Baik \\
Matematika & 4.3 & Baik & 4.15 & Baik \\
Rata-rata & 4.67 & Sangat Baik & 4.68 & Sangat Baik \\
\hline
\end{tabular}

Tabel 2: Hasil Validasi Ahli Pemrograman

\begin{tabular}{lcccc}
\hline \multicolumn{1}{c}{ Mata Pelajaran } & $\begin{array}{c}\text { Aspek } \\
\text { Tampilan }\end{array}$ & Kategori & $\begin{array}{c}\text { Aspek } \\
\text { Pemrograman }\end{array}$ & Kategori \\
\hline IPA & 3.75 & Baik & 4.9 & Baik \\
Bahasa Indonesia & 3.80 & Baik & 5 & Baik \\
Matematika & 4.3 & Sangat Baik & 4.15 & Sangat Baik \\
Rata-rata & 3.95 & Baik & 4.68 & Baik \\
\hline
\end{tabular}


Tabel 3: Hasil Uji Coba Lapangan

\begin{tabular}{lcccccl}
\hline \multirow{2}{*}{ Mata Pelajaran } & \multicolumn{5}{c}{ Uji Coba Lapangan } & \multirow{2}{*}{ Kategori } \\
\cline { 2 - 6 } & & \multicolumn{1}{c}{} & II & Rerata & \\
\hline IPA & 4,2 & 3,9 & 3,9 & 3,9 & 3,9 & Menarik \\
Bahasa Indonesia & 4,1 & 4,4 & 4,3 & 4,4 & 4,3 & Sangat menarik \\
Matematika & 4,0 & 4,3 & 4,3 & 3,9 & 4,17 & Sangat menarik \\
\hline
\end{tabular}

Tabel 4: Hasil Uji Coba Lapangan

\begin{tabular}{|c|c|c|c|c|c|c|}
\hline \multirow{2}{*}{ Mata Pelajaran } & \multicolumn{5}{|c|}{ Uji Coba Lapangan } & \multirow{2}{*}{ Kategori } \\
\hline & $\mathrm{I}$ & II & III & IV & Rerata & \\
\hline IPA & 78,89 & 75.69 & 57,67 & 62,14 & 68,60 & Baik \\
\hline $\begin{array}{l}\text { Ketuntasan Belajar Siswa } \\
\quad \text { (nilai } \geq 60 \text { ) }\end{array}$ & $100 \%$ & $100 \%$ & $45 \%$ & $96 \%$ & $85 \%$ & \\
\hline Bhs Indonesia & 66,88 & 66,08 & 69,91 & 68,18 & 67,76 & Sangat Baik \\
\hline $\begin{array}{l}\text { Ketuntasan Belajar Siswa } \\
\quad(\text { nilai } \geq 60)\end{array}$ & $92 \%$ & $84 \%$ & $91 \%$ & $91 \%$ & $90 \%$ & \\
\hline Matematika & 42.71 & 56,7 & 55 & 354,91 & 52,3 & Sangat \\
\hline $\begin{array}{l}\text { Ketuntasan Belajar Siswa } \\
\quad(\text { nilai } \geq 60)\end{array}$ & $17 \%$ & $48 \%$ & $22 \%$ & $36 \%$ & $31 \%$ & Kurang \\
\hline
\end{tabular}

\section{Revisi Produk}

Pada tahap ini, peneliti menyempurnakan produk multimedia berdasarkan hasil validasi ahli dan uji coba sehingga dihasilkan produk yang lebih baik dari produk awal.

Perbaikan terhadap program dilakukan mulai dari tampilan, isi, serta kelayakan produk supaya dapat digunakan secara luas. Dari aspek tampilan, telah ditambahkan gambar yang menarik minat siswa, serta penambahan musik serta efek suara yang membuat suasana gembira saat menjalankan program pembelajaran. Dari aspek isi, produk ini ditambahkan efek yang lucu, dengan tujuan agar ketika siswa mengerjakan soal akan muncul efek benar atau salah sehingga siswa termotivasi untuk selalu hati-hati dan cermat saat menjawab soal. Dari hasil evaluasi saran dan masukan yang diberikan validator materi, ada perubahan dan perbaikan produk dari segi aspek isi dan pembelajaran materi bagi siswa.

Program bank soal UN telah diberi variasi homogenitas pilihan jawaban serta memberikan tombol pilihan langsung agar siswa langsung masuk ke dalam soal ujian yang diinginkan. Bentuk serta susunan tulisan pada program telah diperbaiki dan dirapikan sehingga siswa merasa nyaman saat membaca dan mengerjakannya.

Berdasarkan saran validator, tombol diletakkan pada bidang yang sesuai sehingga tombol tampil lebih rapi dan tidakmenutupi soal-soal pada program. 
Kemudian, juga ditambahkan menu pembahasan yang di dalamnya tampil nomor soal. Hal tersebut bertujuan agar siswa dapat memilih sendiri nomor soal berapa yang akan dibaca sehingga mereka tidak perlu membaca soal pembahasan mulai dari nomor satu dan seterusnya. Di samping itu, program diberi variasi gambar dan suara efek agar siswa mendapatkan suasana menyenangkan saat menjalankan program pembelajaran ini. Berdasar angket pengamatan yang diberikan kepada guru, kualitas produk ini dinilai baik. Dilihat dari segi kualitas media sebagai alat untuk sarana belajar siswa, peran media ini untuk latihan ujian siswa serta untuk meningkatkan kompetensi siswa dalam mempersiapkan UN. Dari data yang ada, belum semua guru mampu menggunakan pogram ini. Baru beberapa guru yang mampu mengoperasikan komputer dengan baik sehingga program ini juga dibuat lebih sederhana dan mudah dipahami. Dengan demikian, program pembelajaran ini akan mudah dipelajari serta lebih bermanfaat bagi guru dan siswa.

Revisi materi dilakukan pada soalsoal yang memiliki kekurangan atau terdapat kesalahan. Untuk mengantisipasi kesalahan yang berulang, dilakukan pengecekan pada semua soal, baik pada segi kalimat maupun bentuk soal. Selain itu, pengecekan pada pembahasan juga dilakukan untuk mengecek sinkronisasi soal dengan jawaban, serta pembahasan soal. Revisi dari media dilakukan sesuai dengan anjuran dari validator ahli media. Penambahan respons pada pengerjaan soal, dan perubahan bentuk pembahasan pada pro- gram dilakukan untuk membuat tampilan program menjadi lebih baik dan sesuai dengan kebutuhan siswa.

Revisi hasil produk disesuaikan dengan hasil dari validasi ahli materi dan validasi ahli media. Sebagai tindak lanjut terhadap saran validator, perbaikan yang dilakukan meliputi: (1) memastikan bahwa tidak ada gambar yang digunakan untuk dua soal sekaligus; (2) menyempurnakan gambar yang kurang sesuai dengan menggunakan rumus matematika; (3) memberikan menu nomor soal dan pembahasan yang akan dipelajari; (4) membuat tombol klik continue agar siswa tidak bingung mana yang akan diklik; (5) memperjelas petunjuk pengerjaan soal; (6) menambah tombol kembali ke menu utama agar tidak langsung selesai dan masih bisa mengoperasikan program untuk memilih menu lainnya; (7) membuat menu pembahasan soal yang berisi nomor soal yang apabila diklik akan muncul pembahasan sesuai dengan nomor yang diinginkan; dan (8) memberikan efek respons benar/salah.

\section{Hasil Akhir Produk}

Hasil akhir berupa produk multimedia yang telah dikembangkan. Produk ini merupakan perbaikan dari hasil uji coba dan validasi-validasi dari ahli media dan ahli materi, serta berbagai masukan dari pihak-pihak terkait. Pengembangan ini menghasilkan sebuah produk multimedia, yaitu Bank Soal dan Pembahasan Ujian Nasional SD berbasis multimedia pembelajaran interaktif dengan Macromedia Authorware 7.0. Bank soal dan pembahasan yang dikembangkan memuat soal-soal UN 
yang terdiri dari mata pelajaran IPA, bahasan UN Bahasa Indonesia SD, dan Bahasa Indonesia, dan Matematika dari langkah-langkah penggunaannya. tahun 2006/2007, 2007/2008, 2008/2009, $2009 / 2010$, dan 2010/2011.

Berikut adalah salah satu wujud produk pengembangan yang dihasilkan, yaitu aplikasi bank soal dan pem-

- Klik dua kali pada icon authorware yang bertuliskan BAHASA INDONESIA.

- Kemudian tampilan produk authorware akan terbuka.

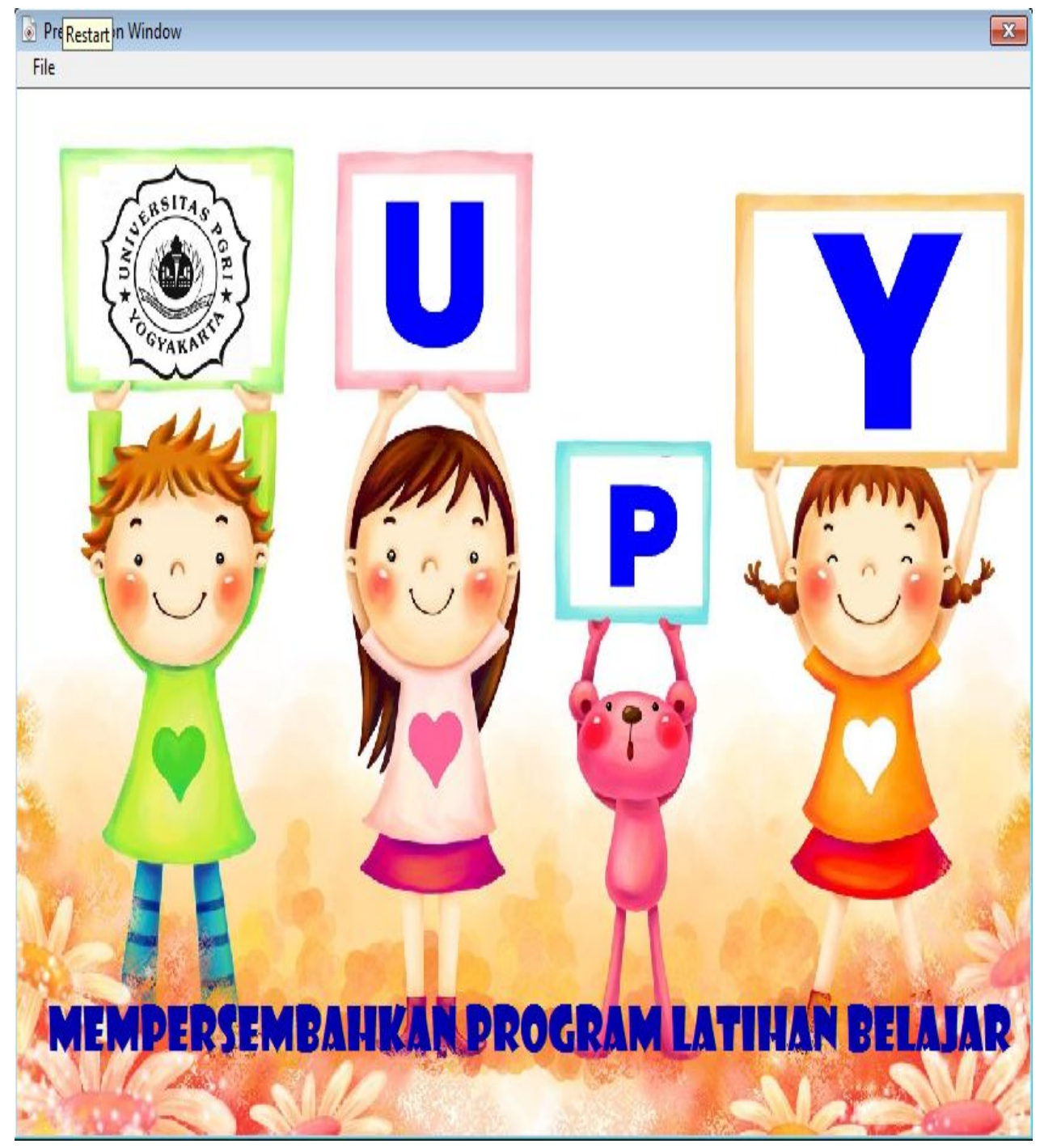

Gambar 2: Tampilan Awal Aplikasi Bank Soal 
- Tunggu sejenak hingga tampilan intro selesai, kemudian klik pada tombol LEWATI.

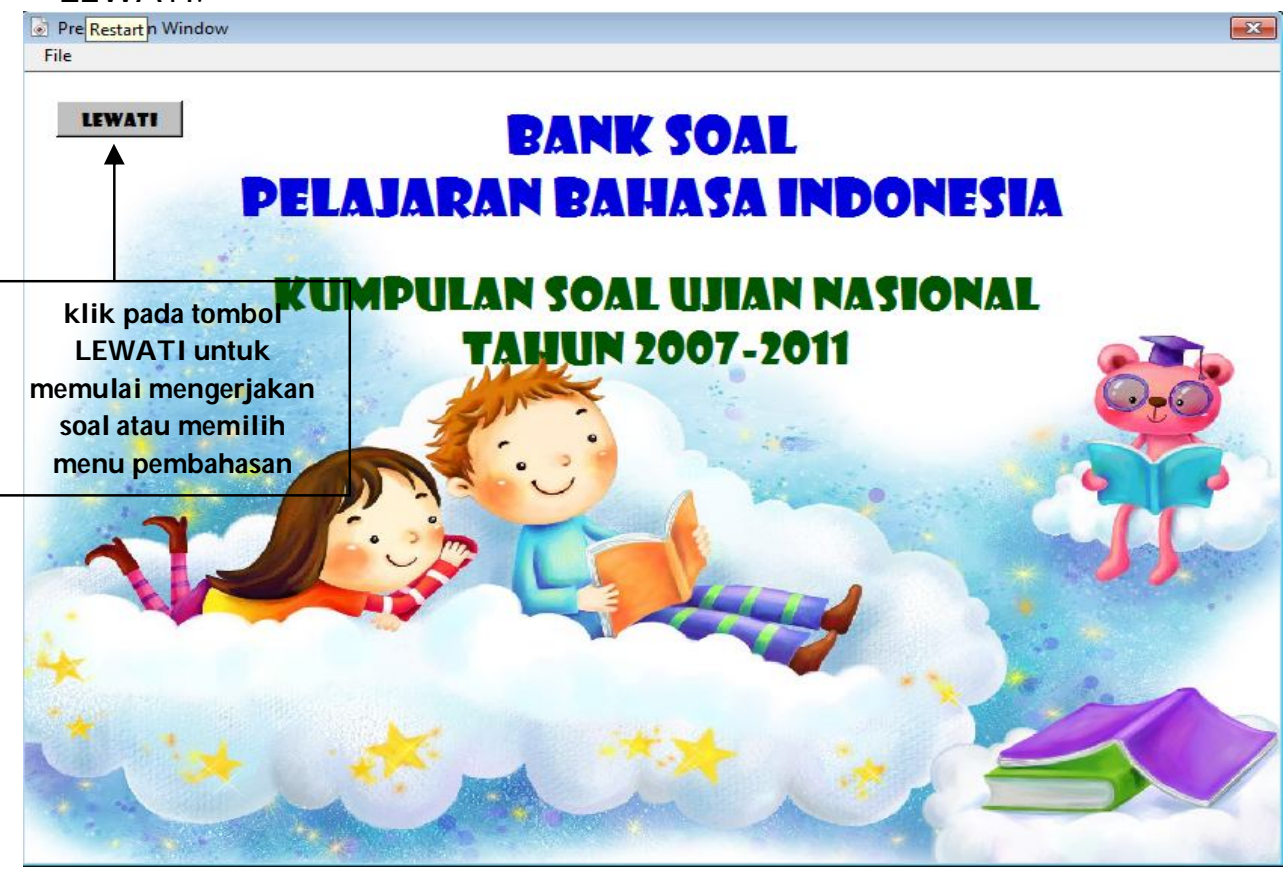

Gambar 3: Tampilan Awal Aplikasi Bank Soal

- Kemudian akan muncul halaman pengisian identitas siswa.

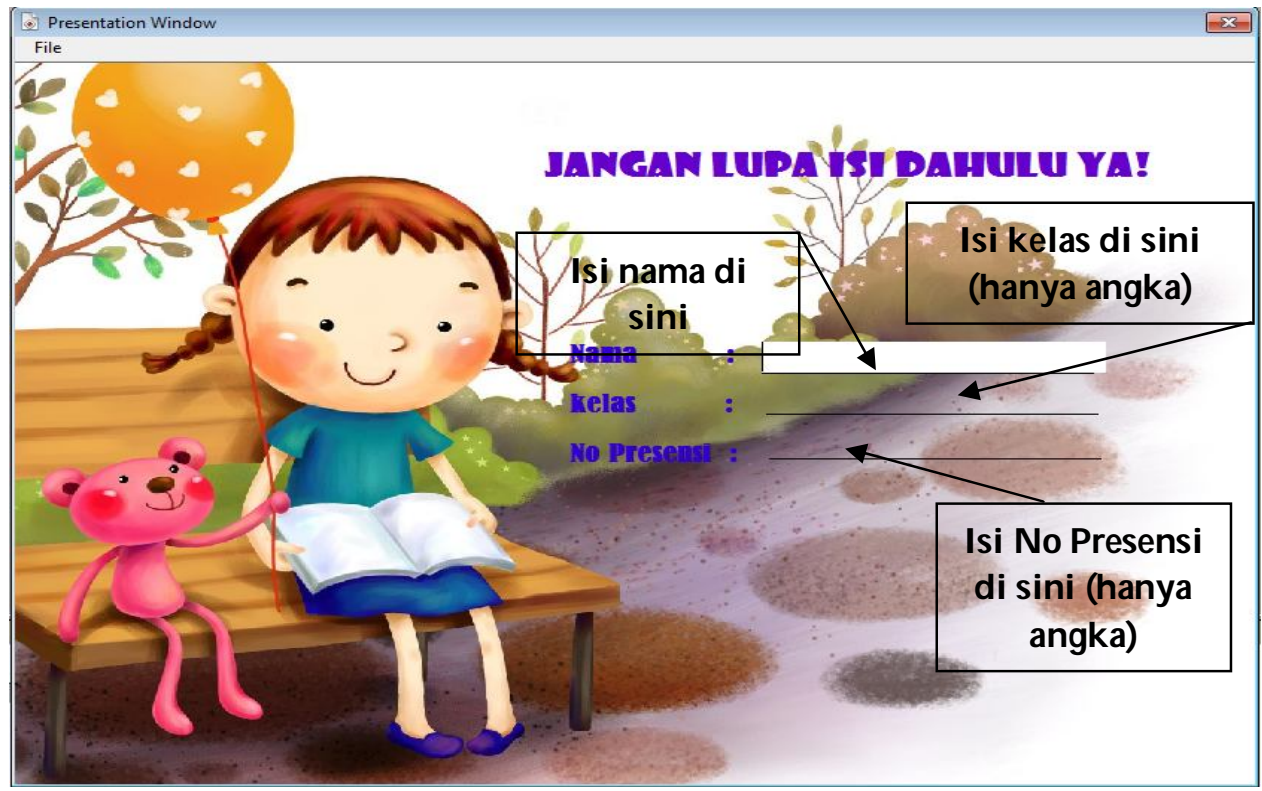

Gambar 4: Halaman Input Identitas 
Pada setiap pengisian identitas diri, klik tombol ENTER pada keyboard untuk mengisi identitas secara berurutan.

- Tampilan selanjutnya adalah MENU UTAMA dalam program. Terdapat pilihan untuk pengerjaan soal, pembahasan, dan menu keluar untuk mengakhiri program.

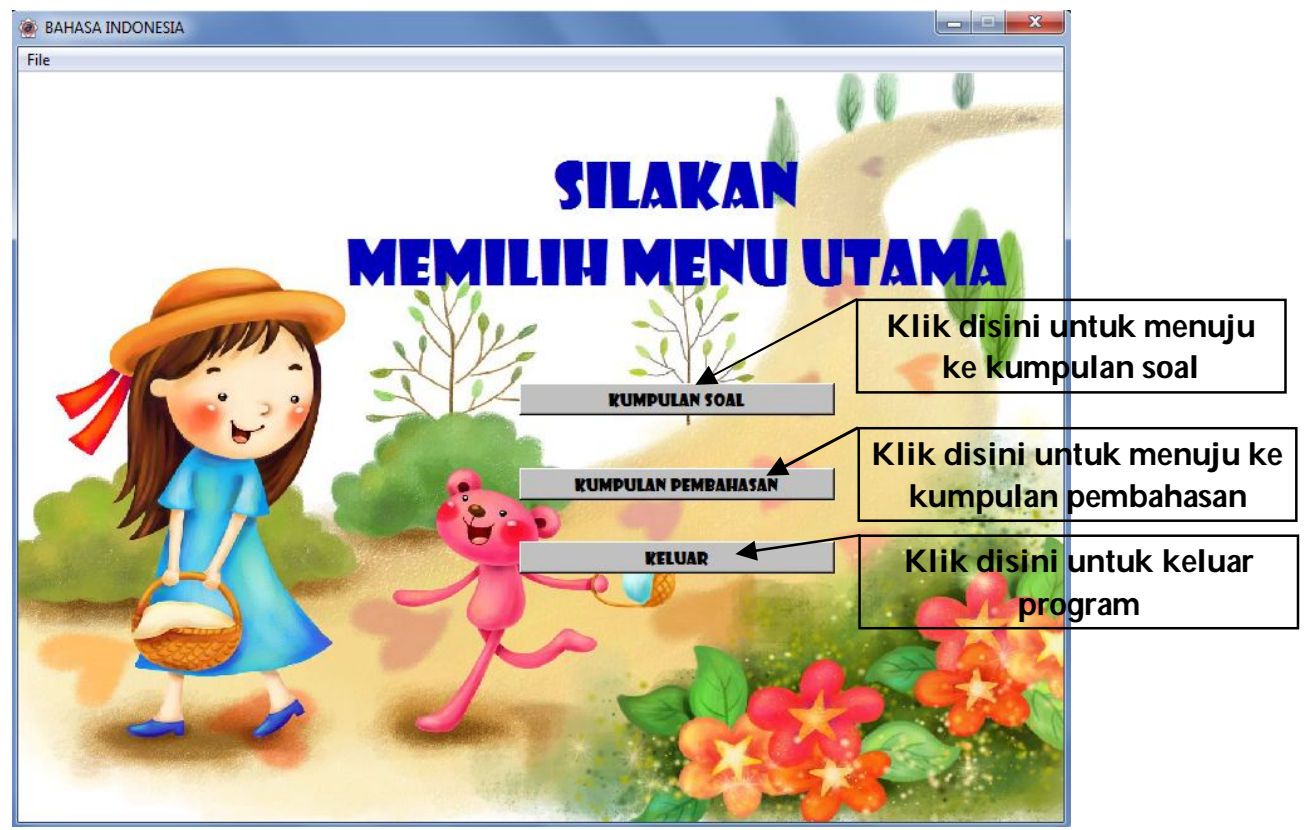

Gambar 5: Halaman Menu Utama

- Apabila menu yang dipilih adalah kumpulan soal, klik satu kali pada KUMPULAN SOAL, maka tampilan selanjutnya adalah halaman kumpulan pilihan soal.

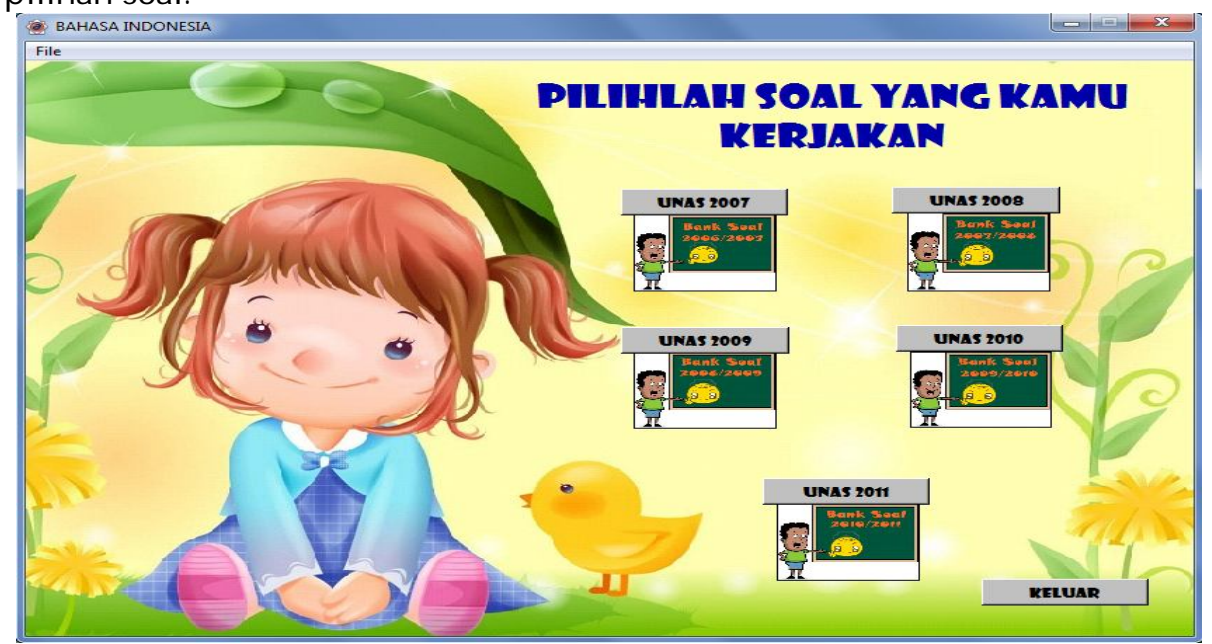

Gambar 6: Halaman Kumpulan Pilihan Soal 
- Misalnya soal yang akan dipilih adalah UNAS 2007, maka langkah selanjutnya adalah melakukan klik satu kali pada UNAS 2007.

- Tampilan selanjutnya yangakan tampil adalah 50 soal UNAS tahun 2007 yang siap untuk dikerjakan. Dalam menjawab soal, tinggal mengeklik satu kali pada pilihan A, B, C, atau D.

- Setiap mengeklik jawaban yang dikehendaki, maka akan muncul efek yang sesuai dengan jawaban. Apabila jawaban benar atau salah, keduanya tetap muncul efek.

- Setelah 50 soal selesai dikerjakan, langkah selanjutnya adalah mengeklik CONTINUE pada pojok kiri atas.

- Klik tombol CONTINUE yang ke dua untuk melihat perolehan nilai.
- Tampilan yang muncul adalah perolehan nilai setelah mengerjakan soal sebelumnya. Untuk melanjutkan tampilan, klik CONTINUE pada pojok kiri atas.

- Untuk menuju ke menu utama, klik CONTINUE kembali.

- Pilihan menu selanjutnya pada tampilan menu utama adalah KUMPULAN PEMBAHASAN. Untuk memilih menu ini, tinggal melakukan klik satu kali pada menu KUMPULAN PEMBAHASAN.

- Apabila menu KUMPULAN PEMBAHASAN dipilih, maka akan muncul pilihan-pilihan kumpulan pembahasan soal UNAS. Misalnya, yang dipilih adalan kumpulan pembahasan UNAS 2007, maka klik satu kali pada UNAS 2007.

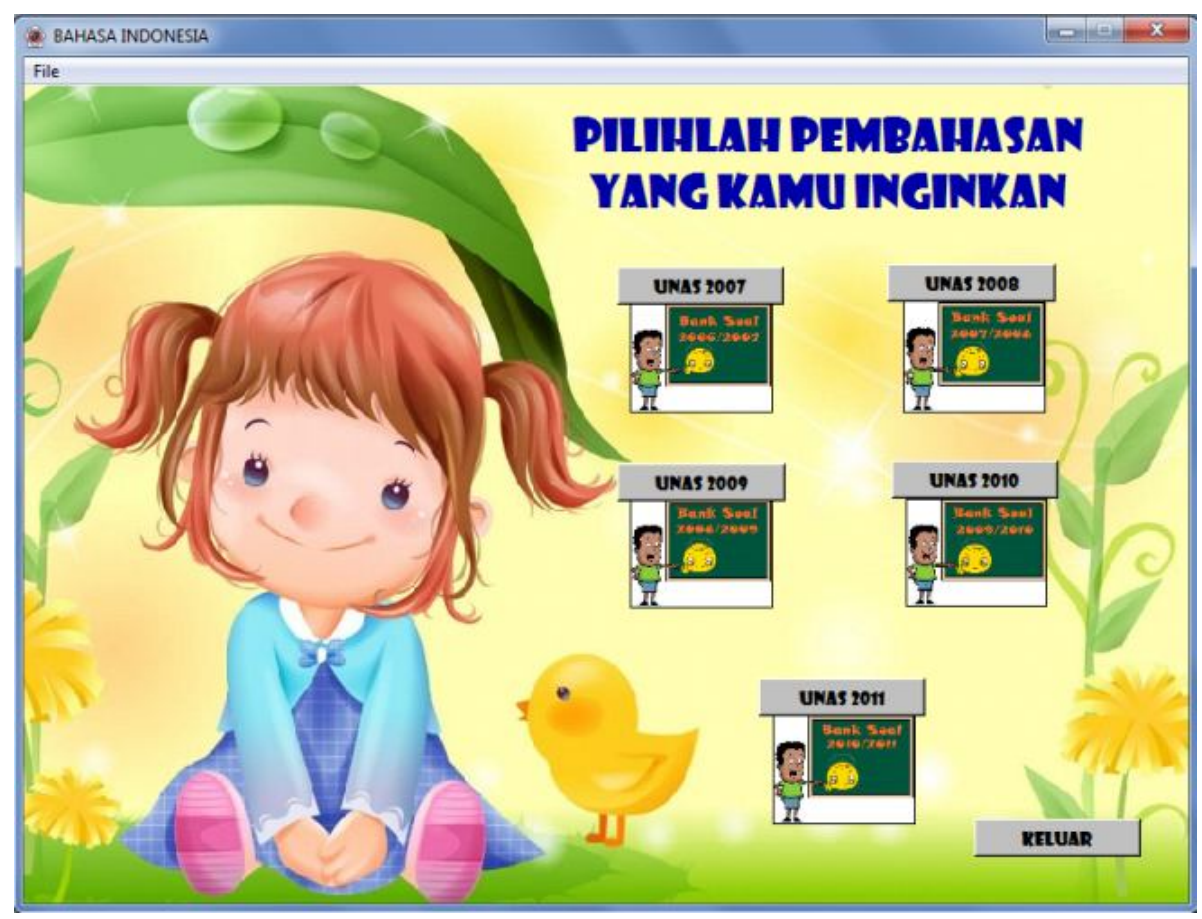

Gambar 7: Halaman Pembahasan Soal 
- Tampilan yang muncul adalah pilihan pembahasan dari soal no 1 sampai 50. Pada bagian ini, pemakai bebas memilih pembahasan yang diinginkan sehingga pemilihan pembahasan tidak harus berurutan, tetapi bisa dilakukan secara acak sesuai keinginan.

- Untuk mengahiri pembahasan, langkah selanjutnya adalah melakukan klik KEMBALI KE MENU UTAMA untuk kembali ke menu utama.

- Untuk mengakhiri semua kegiatan penggunaan produk yang dilakukan, pada menu utama, klik KELUAR.

- Tampilan akan tertutup beberapa saat setelah beberapa tampilan yang muncul sebelumnya secara otomatis.

\section{PENUTUP}

Pengembangan bank soal dan pembahasan UN SD berbasis multimedia pembelajaran interaktif dengan Macromedia Authorware 7.0 telah dilakukan melalui delapan tahap, yaitu analisis kebutuhan, desain pembelajaran, produksi multimedia, validasi desain, revisi desain, uji coba produk, revisi produk, dan produk akhir.

Kualitas bank soal dan pembahasan UN SD berbasis multimedia pembelajaran interaktif dengan Macromedia Authorware 7.0 ditinjau dari aspek isi dan pembelajaran adalah sangat baik. Dengan menggunakan rentang skor 1 sampai 5, aspek isi menunjukkan skor rata-rata 4,67; aspek pembelajaran menunjukkan skor rata-rata 4,68; aspek tampilan menunjukkan skor rata-rata 3,95; dan pemrograman menunjukkan skor rata-rata 4,13. Aspek daya tarik menunjukkan bahwa Bank Soal dan
Pembahasan Ujian Nasional Berbasis Multimedia Pembelajaran Interaktif yang dikembangkan sangat menarik dengan skor rata-rata 4,15. Dari hasil uji coba kelompok besar, persentase ketuntasan belajar siswa di SD Percobaan mencapai rata-rata 85\% dengan kriteria baik pada latihan Ujian Nasional IPA; di SD Negeri Kalimenur mencapai ratarata $90 \%$ dengan kriteria sangat baik pada latihan Ujian Nasional Bahasa Indonesia; di SD Negeri 1 Pengasih mencapai rata-rata $31 \%$ dengan kriteria $s a-$ ngat kurang pada latihan Ujian Nasional Bahasa Matematika.

Produk ini diharapkan mampu untuk membantu siswa dalam mempersiapkan UN sehingga nilai hasil ujian siswa dapat meningkat.

\section{UCAPAN TERIMA KASIH}

Dalam menyelesaikan penelitian ini kami banyak mendapatkan bantuan dari berbagai pihak. Untuk itu, kami ucapkan terima kasih kepada pihakpihak berikut. Pertama, Direktorat Ketenagaan Ditjen Dikti yang telah memberikan dana melalui anggaran hibah DIA BERMUTU. Kedua, reviewer hibah penelitian DIA BERMUTU, yaitu Prof. Dr. Buchory MS, M.Pd, Dra. Murdjanti, M.Pd., dan Dra. Suharni, M.Pd. yang telah memberikan masukan dan saransaran sejak proses seleksi proposal, sampai artikel ini selesai ditulis. Ketiga, para validator ahli materi dan pembelajaran dari SD Percobaan 4, yaitu Singgih Tribowo, S.Pd., Ahmad Daldiri, S.Pd, Giman, S.Pd. dari SDN dan validator ahli media, yaitu Budiharti, S.Si, dosen mata kuliah Media Pembelajaran di PGSD UPY yang telah memberikan 
penilaian dan saran-saran terhadap desain produk. Keempat, Dwi Haryani, Endarto Nugroho, dan Tria Mardiana, para mahasiswa PGSD UPY, yang telah membantu pelaksanaan pengumpulan data dan uji coba produk.

\section{DAFTAR PUSTAKA}

Bloom, Benjamin S, Madaus, George F. dan Hasting, J. Thomas. 1981. Evaluation to Improve Learning. New York: McGraw-Hill Book Company.

Borg, W. R. \& Gall, M. D. 2003. Educational research: an introduction (7th ed.). New York: Longman, Inc.

Daryanto. 2010. Media Pembelajaran: Peranannya sangat Penting dalam Mencapai Tujuan Pembelajaran. Yogyakarta: Gava Media.

Departemen Pendidikan Nasional. 2007. Peraturan Menteri Pendidikan Nasional Republik Indonesia No. 20 tentang Standar Penilaian Pendidikan. Jakarta.
Kustandi, Cecep \& Bambang Sutjipto. 2011. Media Pembelajaran: Manual dan Digital. Bogor: Ghalia Indonesia.

Sadiman, Arief S. dkk. 2006. Media Pendidikan: Pengertian, Pengembangan dan Pemanfaatannya. Jakarta: PT Raja Grafindo Persada.

Sanjaya, Wina. 2009. Perencanaan dan Desain Sistem Pembelajaran. Jakarta: Kencana.

Sudijono, Anas. 2008. Pengantar Evaluasi Pendidikan. Jakarta: PT Raja Grafindo Persada.

Sugiyono. 2009. Metode Penelitian Pendidikan: Pendekatan Kuantitatif, Kualitatif, dan $R \mathcal{E} D$. Bandung: Alfabeta.

Tim Penelitian dan Pengembangan Wahana Komputer. 2004. Membuat Aplikasi Tutorial Interaktif dengan Macromedia Authorware. Jakarta: Salemba Infotek.

Widodo, Chomsin S \& Jasmadi. 2008. Panduan Menyusun Bahan Ajar Berbasis Kompetensi. Jakarta: Elex Media Komputindo. 